\title{
CREATING A PRIMA SERVICE IN BUILDING CUSTOMER SATISFACTION
}

\author{
Rudiatsyah \\ Email: rudiatsah@gmail.com
}

\begin{abstract}
The purpose of this study is to know the purpose of value and customer satisfaction, to know how the company provides value and high satisfaction to customers, to know how companies attract and retain customers, to determine the determination of customer profitability, and to determine the application of total quality marketing in the company. The research method used in this study is a literature review obtained from journals, books, and other relevant sources. Customer satisfaction and loyalty is the most important thing in running a business / business. When running the business the company demanded the power of service provided to the customers. Therefore, the quality of service should receive serious attention from management. Attention to the consumer becomes important, with the effort to listen to the voice of the consumer and then help him to formulate his needs.
\end{abstract}

Keywords: excellent service, satisfaction, customer

\section{Pendahuluan}

Pemenuhan kebutuhan dan keinginan serta nilai kualitas sangat ditentukan oleh tingkat kepentingan maupun kepuasan pelanggan sebagai pemakainya. Pelayanan yang kurang memuaskan akan menyebabkan berkurangnya konsumen bahkan hilang karena konsumen berpindah ke perusahaan yang lain baik dalam bidang penjualan barang maupun jasa yang lain.

Hal ini merupakan tantangan besar bagi perusahaan dalam membangun citra perusahaan yang tidak hanya mampu membuat dan membangun tapi juga dapat memberikan pelayanan yang memuaskan. Oleh sebab itu perusahaan perlu mengetahui perilaku pelanggan dalam membeli, mengguankan dan mengevaluasi barang maupun jasa dalam rangka pemenuhan dan pemuasan kebutuhan.

Setiap perusahaan memiliki tantangan untuk tetap mempertahankan usahanya antara lain bagaimana menjaga kualitas pelayanan agar dapat bersaing dengan produk serupa dan juga produk pengganti lainnya yang saat ini semakin banyak bermunculan. Salah satu Jurnal Akuntansi Dan Pajak, Vol 14, No. 01, Juli 2013 faktor yang harus diperhatikan dalam menjaga kualitas pelayanan yaitu dengan memberikan pelayanan yang memuaskan, sesuai dengan atau melebihi harapan pelanggan. Sehingga dirasakan sangat penting untuk mengetahui pelayanan yang diharapkan oleh pelanggan.

Pada dasarnya kekuatan perusahaan dalam sistem penjualan tergantung dari bagaimana meningkatkan kualitas pelayanan baik melalui peningkatan kualitas produk maupun meningkatkan bagaimana sistem pelayanan terhadap pelanggan.

Kualitas pelayanan lebih menitik-beratkan pada kepuasan pelanggan, di mana kualitas pelayanan berpusat pada upaya pemenuhan kebutuhan dan keinginan pelanggan serta ketepatan penyampaiannya untuk mengimbangi harapan pelanggan (Tho'in, 2011).

\section{Tujuan Penelitian}

Tujuan dari penelitian ini adalah untuk mengetahui maksud nilai dan kepuasan pelanggan, untuk mengetahui cara perusahaan memberikan nilai dan kepuasan yang tinggi 
kepada pelanggan, untuk mengetahui cara perusahaan menarik dan mempertahankan pelanggan, untuk mengetahui penentuan profitabilitas pelanggan, dan untuk mengetahui penerapan total quality marketing di perusahaan

\section{Metode Penelitian}

Metode penelitian yang digunakan dalam penelitian ini adalah berupa kajian pustaka yang diperoleh dari jurnal, buku, dan sumber-sumber lain yang relevan.

\section{Pembahasan}

\section{Nilai dan Kepuasan Pelanggan}

Nilai terantar pada pelanggan adalah selisih antara nilai pelanggan total (total customer value) dan biaya pelanggan total (total customer cost). Dan nilai pelanggan total adalah sebundel manfaat yang diharapkan pelanggan dari barang atau jasa tertentu.

Nilai konsumen (customer value) ditentukan oleh 2 hal yaitu biaya (cost) dan manfaat (benefit). Biaya mencakup biaya uang, waktu, energi, dan psikologi.Manfaat mencakup manfaat produk, jasa, pribadi, dan image. Manfaat yang dirasakan oleh setiap konsumen berbeda-beda.Satu manfaat bisa menjadi lebih penting dibanding manfaat lainnya. Berbeda dengan manfaat, biaya bersifat mutlak dan merupakan akumulasi dari seluruh biaya yang ada, hanya saja terkadang konsumen tidak menyadari biaya lain selain biaya uang.

Jika manfaat > biaya, maka akan tercipta nilai konsumen yang tinggi (superior customervalue), sedangkan jika manfaat < biaya, maka akan tercipta nilai konsumen yang rendah (inferior customer value). Untuk mencapai kepuasan konsumen, maka perusahaan perlu memberikan nilai konsumen (red: superior) yang lebih baik daripada pesaingnya.

Jurnal Akuntansi Dan Pajak, Vol 14, No. 01, Juli 2013
Kotler (2002), secara umum ia menyatakan bahwa "Kepuasan adalah perasaan senang atau kecewa seseorang yang muncul setelah membandingkan antara persepsi/kesannya terhadap kinerja (atau hasil) suatu produk dan harapan-harapannya".

Kepuasan konsumen(consumer satisfaction) terjadi ketika perusahaan dapat memenuhi kebutuhan, keinginan dan harapan dari konsumennya. Jadi, tingkat kepuasan merupakan fungsi dari perbedaan antara kinerja yang dirasakan (perceived performance) dan harapan (expectations).

Empat metode yang dapat digunakan oleh perusahaan untuk memantau dan mengukur kepuasan pelanggan menurut Tjiptono (2006:146), yaitu :

1. Sistem Keluhan dan Saran

Setiap perusahaan yang berorientasi pada pelanggan (customer oriented) perlu memberikan kesempatan seluas luasnya bagi para pelangganya untuk menyampaikan saran, pendapat, dan keluhan mereka, sehingga dapat memberikan ide-ide baru dan masukan yang berharga kepada perusahaan.

2. Survei Kepuasan Pelanggan

Pengukuran kepuasan pelanggan melalui metode ini dapat dilakukan dengan berbagai cara diantaaranya, sebagai berikut:

a. directly reported satisfaction

Pengukuran dilakukan secara langsung melalui pertanyaan.

b. derived dissatisfaction

Pertanyaan yang diajukan yakni besarnya harapan pelanggan terhadap atribut tertentu dan besarnya kinerja yang mereka rasakan.

c. problem analysis

Konsumen yang dijadikan responden diminta untuk mengungkapkan dua hal yaitu masalah yang mereka hadapi berkaitan dengan penawaran dari 
perusahaan dan saran-saran untuk melakukan analisis.

d. Importance performance analysis

Dalam teknik ini responden diminta untuk merangking berbagai elemen dari penawaran berdasarkan derajat pentingnya setiap elemen dan diminta untuk merangking seberapa baik kinerja perusahaan dalam masing-masing elemen tersebut.

3. Ghost Shopping

Metode ini dilaksanakan dengan mempekerjakan beberapa orang untuk berperan dan bersikap seperti pelanggan atau pembeli yang potensial dari produk perusahaan dan pesaing.

4. Lost Costumer Analysis

Metode ini cukup unik. Perusahaan berusaha menghubungi para pelanggannya yang telah berhenti membeli atau beralih pemasok.

Kepuasan konsumen akan menyebabkan para pesaingnya berusaha keras merebut atau mempertahankan konsumen suatu perusahaan. Kepuasan konsumen merupakan strategi jangka panjang yang membutuhkan konsumen baik dari segi dana maupun sumber daya manusia (Schnaars,1991). Beberapa strategi yang dipadukan untuk meraih dan meningkatkan kepuasan pelanggan adalah:

a. Relation Marketing (Mc Kenna, 1991) yaitu strategi dimana transaksi pertukaran antara pembeli dan penjual berkelanjutan, tidak berakhir setelah penjualan selesai. Relationship Marketing berdasar pada:

1) Fokus customer retention

2) Orientasi manfaat produk

3) Orientasi jangka panjang

4) Layanan pelanggan yang sangat diperhatikan dan ditekankan
5) Komitmen terhadap konsumen sangat tinggi

6) Kontak dengan pelanggan sangat tinggi

7) Kualitas yang merupakan perhatian sangat tinggi

b. Strategi Superior Customer Service (Schnaars,1991).Strategi ini menawarkan strategi yang lebih baik daripada pesaing. Perusahaan atau organisasi yang menggunakan strategi ini harus memiliki dana yang cukup besar dan kemampuan SDM yang unggul, serta memiliki usaha yang gigih agar tercipta suatu pelayanan yang menawarkancustomer service yang lebih baik akan membebankan harga yang lebih tinggi daripada produk atau jasa yang dihasilkan.

c. Strategi unconditional guarantees (Hart, 1988) atau extra ordinary guarantees. Strategi ini berintikan komitmen untuk memberikan kepuasan konsumen yang akhirnya akan menjadi sumber dinamisme penyempurnaan mutu produk atau jasa dan kinerja perusahaan.

d. Strategi penanganan keluhan yang efisien (Schnaars, 1991) Memberikan peluang bagi perusahaan untuk mengubah konsumen yang tidak puas (unsatisfied customer) menjadi konsumen yang puas (satisfied customer) terhadap produk atau jasa yang dihasilkan perusahaan.

e. Strategi peningkatan kinerja perusahaan. Suatu strategi meliputi berbagai upaya seperti melakukan pemantauan dan pengukuran kepuasan konsumen secara berkesinambungan, memberikan pendidikan dan pelatihan yang mencakup komunikasi dan public relation terhadap pihak manajemen dan karyawan, memasukkan unsur 
kemampuan untuk memuaskan konsumen yang penilaiannya bias didasarkan pada survei konsumen, dalam sistem penilaian prestasi karyawan dan memberikan enpowerment yang lebih besar kepada karyawan dalam melaksanakan tugasnya.

f. Penerapan Quality Function Deployment (QFD).Merupakan praktek dalam merancang suatu proses sebagai tanggapan terhadap kebutuhan konsumen. Hal ini melibatkan konsumen dalam proses mengembangkan produk/jasa sedini mungkin dengan demikian memungkinkan perusahaan untuk memperioritaskan kebutuhan konsumen serta memperbaiki proses hingga tercapainya efektivitas maksimum.

Sehubungan dengan pentingnya nilai dan kepuasan pelanggan, bagaimana cara menghasilkan serta menyampaikannya? Untuk menjawabnya, kita perlu mengenal konsep rantai nilai (value chain) dan sistem pengantaran nilai (value-delivery system).

\section{Rantai Nilai}

Rantai nilai merupakan kumpulan aktivitas atau kegiatan dalam sebuah perusahaan yang dilakukan untuk mendesain, memproduksi, memasarkan, mengirimkan, dan support produk. Dalam konsep ini perusahaan harus mencermati biaya dan kinerja dalam setiap aktivitas serta harus memperhatikan pesaing karena cara ini merupakan alat utama untuk mengidentifikasi cara menciptakan nilai bagi pelanggan yang lebih tinggi.

2. Sistem Pengantaran Nilai

a. Memilih nilai, mempresentasikan pekerjaan rumah pemasaran yang harus dilakukan sebelum produk dibuat. Staf pemasaran harus mensegmentasikan pasar, memilih sasaran pasar yang tepat, dan mengembangkan penawaran positioning nilai.

b. Menyediakan nilai. Pemasaran harus menentukan fitur produk tertentu,harga, dan distribusi.

c. Mengomunikasikan nilai dengan mendayagunakan tenaga penjualan, promosi penjualan, iklan dan sarana komunikasi lain untuk mengumumkan dan mempromosikan produk.

\section{Menarik Pelanggan}

Perusahaan masa kini perlu lebih memperhatikan tingkat kehilangan pelanggan dan mengambil berbagai langkah untuk menguranginya, ada 4 langkah yaitu :

1. Perusahaan harus menentukan dan mengukur tingkat bertahannya pelanggan. Bagi sebuah majalah, ukurannya adalah tingkat langganan ulang, bagi sebuah universitas mungkin tingkat bertahanya mahasiswa tingkat pertama ke tingkat kedua, atau tingkat kelulusan mahasiswanya

2. Perusahaan harus membedakan berbagai penyebab hilangnya pelanggan dan mengidentifikasi penyebab-penyebab yang bisa ditangani secara lebih baik.

3. Perusahaan harus mengestimasi besarnya keuntungan yang hilang akibat hilangnya pelanggan secara tidak perlu.

4. Perusahaan perlu menghitung jumlah biaya untuk mengurangi tingkat kehilangan pelanggan.

Dengan semakin ketatnya persaingan maka perusahaan merasa perlu untuk mempertahankan pelanggannya agar pelanggan tersebut tidak lari ke perusahaan lain. Oleh karena itu digunakan berbagai macam cara untuk menarik dan mempertahankan pelanggan, antara lain :

1. Memberikan potongan tarif (discount) kepada pelanggan yang setia 
2. Memberikan service/pelayanan yang lebih baik dibanding perusahaan lain yang sejenis

3. Meningkatkan kualitas dan terus berinovasi karena produk juga akan selalu dinamis

Mempertahankan pelanggan adalah yang paling utama, ada dua cara untuk mencapainya.Pertama menciptakan hambatan beralih pemasok yang besar. Pelanggan cenderung tidak akan beralih pemasok jika biaya modalnya tinggi, biaya pencariannya tinggi, potongan sebagai pelanggan setianya hilang, dan lain-lain.

Cara yang lebih baik untuk mempertahankan pelanggan adalah dengan memberikan kepuasan pelanggan yang tinggi.Dengan demikian, akan lebih sulit bagi para pesaing untuk menerobos hambatanhambatan dengan sekedar menawarkan harga yang lebih murah atau rangsangan beralih pemasok. Tugas menciptakan loyalitas pelanggan yang kuat disebut relationship marketing.

Berry dan Parasuraman membedakan tiga pendekatan penciptaan nilai pelanggan, yaitu: Pertama, berdasarkan penambahan manfaat financial bagi hubungan pelanggan. Kedua, menambahkan manfaat sosial disamping manfaat financial. Disini karyawan perusahaan meningkatkan ikatan sosial mereka dengan pelanggan melalui pemahaman atas kebutuhan dan keinginan individual para pelanggan, serta penyampaian layanan yang lebih bersifat pribadi/personal. Ketiga, menambahkan ikatan struktural disamping manfaat financial dan sosial.

\section{Kesimpulan}

Nilai penjualan produk ditentukan oleh bagaimana melakukan pelayanan yang optimal terhadap pelanggan, untuk menjaga kepuasan kepada pelanggan adalah dengan menjaga kualitas dari produk yang akan dijual. Kualitas pelayanan merupakan tingkat keunggulan Jurnal Akuntansi Dan Pajak, Vol 14, No. 01, Juli 2013 yang diharapkan dan pengendalian atas tingkat keunggulan tersebut untuk memenuhi harapan pelanggan. Kepuasan konsumen merupakan modal dasar untuk membentuk loyalitas yang bisa dijadikan sebagai salah satu senjata untuk menaikan keunggulan bersaing suatu perusahaan yang bergerak di sector jasa atau produk. Kepuasaan dan loyalitas pelanggan merupakan hal terpenting dalam menjalankan bisnis/usaha. Saat menjalankan bisnisnya perusahaan dituntut adanya kekuatan service yang diberikan kepada pelanggan.Oleh karena itu, kualitas pelayanan harus mendapat perhatian yang serius dari manajemen. Perhatian terhadap konsumen menjadi penting, dengan adanya upaya untuk mendengarkan suara konsumen dan kemudian membantunya untuk memformulasikan kebutuhannya.

\section{Daftar Pustaka}

Kotler, Philip, (2002), Manajemen Pemasaran, Jilid 1, Edisi Milenium, Jakarta, Prehallindo.

McKenna. R. (1991). "Relationship Marketing: Successful Strategies for the Age of the Customer, Reading, Massachusetts: Addison-Wesley Publishing Company", Ventura, Journal of Marketing, vol. 5, No. 2, Desember.

Schnaars, Steven P. (1991). Marketing Strategy: A customer Driven Approach.2nd ed. New York: The Free Press.

Tho'in, M. (2011). Pengaruh Faktor-faktor Kualitas Jasa terhadap Kepuasan Nasabah di Baitul Mal Wat Tamwil (BMT) Tekun Karanggede Boyolali. MUQTASID Jurnal Ekonomi dan Perbankan Syariah, 2(1), 73-89.

Tjiptono; Fandi. (2006). Pemasaran Jasa. Edisi Pertama, Yogyakarta: Andi Yogyakarta. 